\title{
Amerika domates genetik kaynakları merkezinden temin edilen domates hatlarının Fusarium etmenlerine karşı dayanıklılık reaksiyonlarının belirlenmesi
}

\author{
Identification of resistance reactions of tomato accessions to Fusarium pathogens \\ obtained from American tomato genetics resources center
}

\author{
Semra CAN@, Gülşen ERBERKゅ, Özer ÇALIŞ@ \\ Akdeniz Üniversitesi, Ziraat Fakültesi, Bitki Koruma Bölümü, Kampüs, 07059, Konyaaltı, Antalya \\ Sorumlu yazar (Corresponding author): Ö. Çalış, e-posta (e-mail): ozercalis@akdeniz.edu.tr \\ Yazar(lar) e-posta (Author e-mail): cansemra07@gmail.com, gl.brk512@hotmail.com
}

\section{MAKALE BİLGİSI}

Alını̧ tarihi 30 Nisan 2020

Düzeltilme tarihi 02 Eylül 2020

Kabul tarihi 04 Eylül 2020

\section{Anahtar Kelimeler:}

Domates

Fusarium solgunluğu

Patojenisite

Dayanıklılık

\begin{abstract}
ÖZ
Domates Türkiye'de ve dünya'da en çok üretimi yapılan sebzelerden birisidir. Özellikle Antalya ilinde kışlık domates üretiminin \%60'dan fazlası üretilmektedir. Üretimin yoğun yapıldığı domates seralarında çok ciddi biyotik hastalık etmenleri bulunmaktadır. Domateste üretimini sınırlayan önemli hastalık etmenlerinden birisi, kök ve kök boğazı çürüklüklerine neden olan Fusarium etmenleridir. Bu çalışmanın amacı; domates üretiminde sorun olan yerel Fusarium oxysporum f.sp. lycopersici izolat 14 (FOL14) ve Fusarium oxysporum f.sp. radicislycopersici izolat 12 (FORL12) etmenlerine karşı Amerika Domates Genetik Kaynakları Merkezinden (TGRC) temin edilen 20 domates hattının testlenerek reaksiyonlarının belirlenmesidir. Patojenisite testleri LA3473 (S. lycopersicum) bitkilerinin FORL12'ye çok hassas olduğunu ve inokulasyondan 21 gün sonra tüm bu bitkilerin öldüğünü göstermiştir. Testlenen 20 domates hattının FOL14'e karşı dayanıklı oldukları bulunmuştur. Böylece ilk defa Antalya domates üretim alanlarından izole edilen Fusarium etmenleri uluslararası bilinen 20 domates hattıyla testlenmiştir. Testlenen bu hatlar gerek anaç olarak gerekse sahip oldukları genetik dayanıklılık özellikleriyle Fusarium etmenlerinin kontrolünde kullanılabilecektir.
\end{abstract}

\section{ARTICLE INFO}

Received 30 April 2020

Received in revised form 02 September 2020 Accepted 04 September 2020

\section{Keywords:}

Tomato

Fusarium wilt

Pathogenicity

Resistance

\begin{abstract}
Tomato is one of the most important vegetable in the world and Turkey. Especially, Antalya province has been producing more than $60 \%$ of winter tomato production alone in Turkey. There are very serious biotic diseases that limit the production of tomatoes in this intensive production area. One of the major disease pathogens which restrict the production of tomato is soil-borne Fusarium species. Aims of the study to investigate resistance reactions of local Fusarium oxysporum f.sp. lycopersici isolate 14 (FOL14) and Fusarium oxysporum f.sp radicis-lycopersici isolate 12 (FORL12) with inoculating 20 tomato accessions obtained from Tomato Genetic Resources Center (TGRC). Pathogenicity tests revealed that only LA3473 (S lycopersicum) plants were enhanced susceptible and died at 21 post days inoculation to FORL12 isolate. However, all tested 20 tomato accessions against FOL12 were resistant found. Therefore, local Fusarium isolates have tested against internationally known tomato lines. These resistant accessions either rootstocks or genetic resistance sources will be used to control Fusarium species.
\end{abstract}

\section{Giriş}

Domates dünyada ve ülkemizde en yaygın üretilen ve tüketilen aynı zamanda ekonomik olarak önemli yere sahip olan sebzelerden birisidir. Günümüzde domates genelde taze tüketildiği gibi daha çok gıda sanayinde dondurulmuş, kurutulmuş ve salça olarak da tüketilmektedir (Paksoy 2003; Türkomp 2016). Türkiye'de domates üretimi özel bir yere sahiptir. Açıkta ve seralarda yapılan domates üretimi ticari olarak her yıl artarak devam etmektedir. Domates üretimi ülkemizde en fazla Akdeniz Bölgesi'nde (3137800 ton), il olarak ise Antalya'da (2421247 ton) yapilmaktadır (TÜİK 2019). Bu veriler Türkiye'nin dünya domates üretiminde önemli 
bir paya sahip olduğunu ve ekonomik açından üretimde büyük bir değer oluşturduğunu göstermektedir (FAO 2020).

Domates yetiştiriciliği sırasında karşılaşılan hastalık ve zararlılar ciddi sorunlar oluşturmaktadır. Gerek örtü altı gerekse açık alanlarda yetiştirilen domateslerde kalite ve ürün kaybında biyotik ve abiyotik faktörler önemli derecede etkili olmaktadır. Etkisi açısından en önemli biyotik etmenler funguslar, bakteriler ve virüslerden oluşmaktadır (Aktaş 2015). Tarım ürünlerinde olduğu gibi açık ve kapalı alanlarda yetiştirilen domates bitkileri birçok hastalık etmeninin tehditi altındadır. Domateste Fusarium hastalıklarına neden olan toprak kökenli fungal etmenler büyük ürün kayıplarına neden olmaktadır (Agrios 2005). Hastalığa dair ilk kayıtlar, Japonya ve ABD'de gerçekleştirilmiştir (Agrios 2005). Hastalık etmeni patojenin iki farklı alt-türü vardır: $F$. oxysporum f.sp. lycopersici (Snyder ve Hansen 1940) vasküler solgunluğa ve $F$. oxysporum f.sp. radicis-lycopersici (Jarvis ve Shoemaker 1978), taç ve kök çürümesine neden olmaktadır. Her iki Fusarium etmeni toprak kaynaklıdır ve domates yetiştiriciliği yapılan alanların çoğunda görülmektedir (Agrios 2005).

Fusarium türleri, dünyada Antartika kıtası hariç tundra, çöl, tropik ve subtropik iklimlere adapte olmuş bitkilerde hastalıklar oluşturmaktadırlar. Fusarium türleri birçok kültür bitkisinde patojenik olabildiği gibi fillosfer ve rizosferde saprofitik olarak yaşamlarını sürdürebilmektedirler (Gordon ve Martyn 1997).

FOL, toprak kökenli bitki patojeni olup Hyphomycetes sinıfi bir fungustur. Domateste oluşturduğu Fusarium solgunluğu (wilt) belirtisi ile bilinen hastalık ilk defa 1895 yllında İngiltere'de tanımlanmıştır. FOL özellikle sıcak iklime sahip alanlarda sıklıkla büyük ürün kayıplarına neden olmaktadır. Amerika Birleşik Devletlerinde tek bir üretim sezonunda Florida ve diğer güney eyaletlerde tüm domates üretimini yok ettiği bilinmektedir (Agrios 2005).

FORL birçok bitki türünün rizosfer bölgesinde ortaya çıkan ölü dokularla beslenen, nekrotrof bir fungustur. Patojen geniş bir konukçu bitki türüne sahiptir (Agrios 2005). Hastalıktan etkilenen alt yapraklarda sararmalar başlamakta ve yaprak kısa süre sonra hemen düşmektedir. Belirtiler bitkinin gövdesinde ya da yapraklarında tek taraflı olarak görülmektedir. Sararan yapraklarda solgunluk ve ölümler gerçekleşmekte olup hastalanan kökler ve yan kökler siyah bir renk alarak çürümektedirler. Hastalıktan etkilenen bitkiler bir an önce generatif döneme geçmekte ve bu bitkiler ya cüce kalmakta ya da hiç meyve vermemektedir. Eğer ana gövde kesilirse gövde boyunca koyu kahverengi bir çizginin uzandığ1 görülür. $\mathrm{Bu}$ kahverengi çizgi gövdeden çiçeğin taç yaprağına kadar tüm iletim sisteminin etkilediğini göstermektedir (Agrios 2005). Fide devresinde hastalık belirtisi ilk önce solgunluk olarak kendini gösterir ve daha sonra fideler ölmektedir. Köklerin ölmesinden dolayı bitkiler sararmakta ve solmaktadır. Bitkilerin toprak yüzeyine yakın gövdesinden enine kesit alındığında iletim demetlerinde kahverengi halka görülmekte olup renk değişimi gövdenin üst kısımlarına kadar ilerlemektedir (Jones ve ark. 1991).

Fusarium kök çürüklüğüne karşı kültürel mücadele çok etkili bir mücadele yöntemi değildir. Bitkilerin mümkün olduğunca uzun süre hastalıktan etkilenmemesi için; eski nekroz oluşturmuş köklerin yerine geçebilecek yeni köklerin oluşabilmesi amacı ile bitkilere boğaz doldurması yapılmalıdır. Topraksız kültürde (torf veya volkanik tüf + torf) daha fazla kök elde etmek için kök boğazına biraz torf eklenmelidir (Agrios 2005). Güneş enerjisiyle toprak sterilizasyonu, sıcak iklim koşulları altında başarılı olmasına karşın serin iklim koşulları için pratik olmamaktadır. Seralarda toprağa solarizasyon uygulaması hastalık etmenin kontrolünde en etkili yöntemdir (Agrios 2005). Hastalıkla mücadelede hizlı bir tohum çimlenmesi ve fide gelişiminin olması ve bitkide bağışıklığın kazandırılması ile ileri dönem hastalıklarına karşı da koruma sağlanması önemlidir (Aşkın 2008).

Sistemik etkili fungisit uygulamaları bitki köklerine lokal sulama ile veya gübre uygulama sistemleri ile verilebilir. Fusarium'un 1rkları bu sistemik fungisitlere karşı birkaç uygulamadan sonra dayanıklı hale geçmektedirler. Üstelik bu ilaçlar topraksız kültürde kaya yünü üzerinde bazı fitotoksisite risklerini taşımaktadır (Jones ve ark. 1991; Blancard 1994). Fungisitler fungal hastalıkların mücadelesinde ümit verici olmalarına karşın, fitotoksite, çevre kirliliği ve insan sağlı̆̆ına zararlı etkileri nedeniyle problem oluşturmaktadırlar (Vellaisamy 2002).

Hastalık etmenini genel olarak dayanıklı çeşitlerin kullanılmasıyla kontrol altına alınabilmektedir. $F O L$ irk 1 ve 2'ye karşı hem poligenik hem de monogenik genler dayanıklılığ sağlamaktadır. FOL ırk 3'e karşı son zamanlarda monogenik dayanıklı domatesler geliştirilmiştir (Catanzariti ve ark. 2014) FORL hastalık etmenine karşı dayanıklı domates bitki materyalleri ve $\mathrm{Frl}$ dayanıklılık genleri dominant karakterde dayanıklılığı sağlamaktadır (Devran ve ark. 2018).

Günümüzde Fusarium hastalıklarına dayanıklı domates çeșitlerinin çoğu yurt dışından getirilmektedir. Ancak yurtdışındaki Fusarium izolatlarına karşı dayanıklılığı bilinen bu domatesler Türkiye'deki Fusarium izolatlarına karşı aynı dayanıklılı̆̆ sağlayamamaktadırlar. $\mathrm{Bu}$ çalışmanın amacı Antalya ilinden toplanan yerel 2 Fusarium türüne karşı Amerika Domates Genetik Kaynaklarından temin edilen 20 domates hattının dayanıklılık durumlarını belirlemektir.

\section{Materyal ve Yöntem}

Çalışmada kullanılan FOL ve FORL izolatları 2015-2016 yıllarında yapılan güdümlü örnekleme sürveylerinde toplanmıştır. Antalya ve ilçelerinde domates üretilen alanlarda kök ve kök boğazı hastalık belirtisi gösteren seralardan 18 Fusarium izolatı elde edilmiş olup bu izolatlardan en virulent olan FOL14 race 2 ve FORL12 çalışmalarda kullanılmıştır. Bu FOL14 race 2 ve FORL12 izolatları Amerikan Domates Genetik Kaynakları (TGRC) merkezinden temin edilen 20 domates hatt1 (Şekil 1) üzerine 10 ar tekerrürlü olarak inokule edilerek testlenmiştir.

Çalıșma, Akdeniz Üniversitesi Ziraat Fakültesi Moleküler Mikoloji Laboratuvarında gerçekleştirilmiştir. TGRC den temin edilen 20 domates hattının tohumları Akdeniz Üniversitesi Ziraat Fakültesi seralarında torf-perlit (1 volüm:1 v) karışımı içeren saksılarda çimlendirilerek gelişen fideler aynı karışımı içeren büyük saksılara şaşırtılmıştır. Gerek çimlenme gerekse saksılara şaşırtılan domates bitkileri 14 saat (s) gündüz ve $10 \mathrm{~s}$ gece 1 şık rejiminde ve $24 \pm 3^{\circ} \mathrm{C}$ sıcaklığında tutulmuşlardır. Bu koşullarda yetiştirilen 3-4 gerçek yapraklı bitkilerin kök ve çevresine $10 \mathrm{ml} 2 \times 10^{6}$ spor ml $^{-1}$ konsantrasyonunda Patates Dekstroz Broth (PDB) ortamında geliştirilen (Şekil 2a) makro ve mikrokonidia sporlarından oluşan inokulum bırakılmıştır. Patojenisite testlerinin etkinliğini artırmak için spor inokulasyonundan 3 gün sonra Patates Dekstroz Agar (PDA) besi yerinde geliştirilen (Şekil 2b) FOL14 race 2 ve FORL12 izolatlarından mantar delici (corkborer) ile $5 \mathrm{~mm}$ çapında alınan diskler bitkilerin kök çevresine bırakılmıştır. 


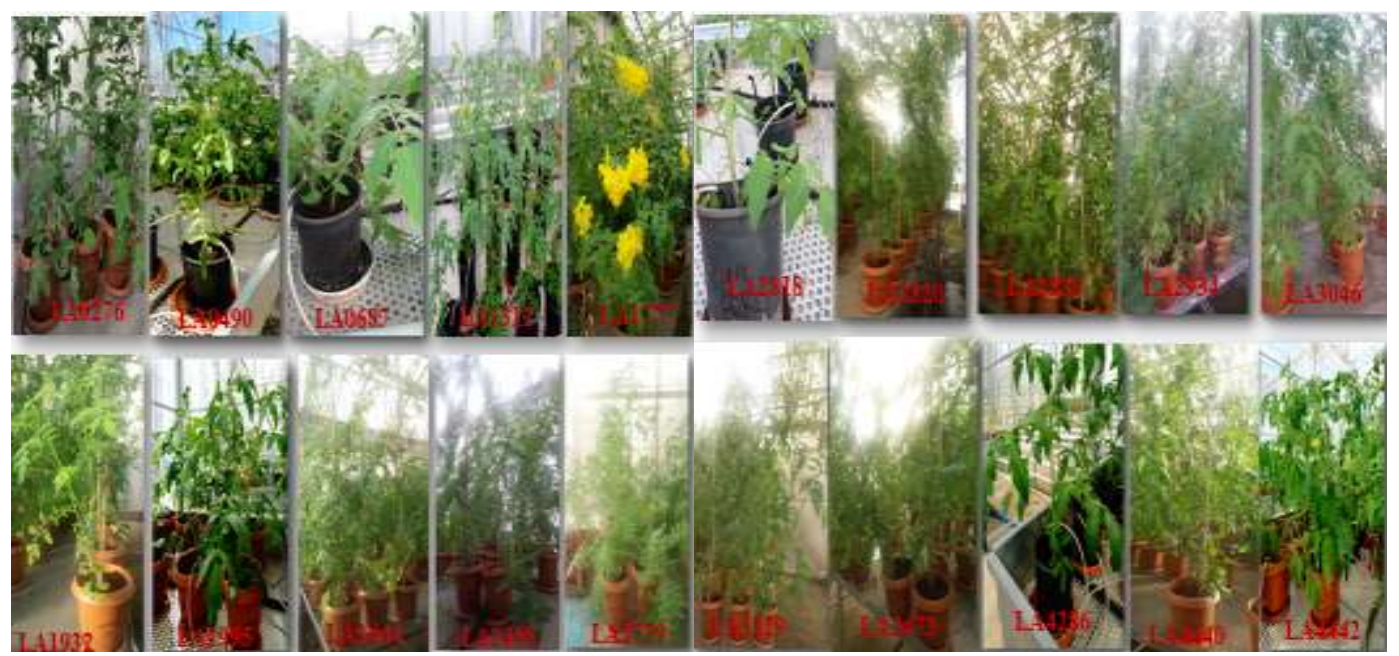

Şekil 1. Amerika Domates Genetik Kaynakları Merkezinden temin edilen 20 domates hattının fenotipik görünümü.

Figure 1. Phenotypes of 20 tomato accessions obtained from American Tomato Genetics Resources Center (TGRC).
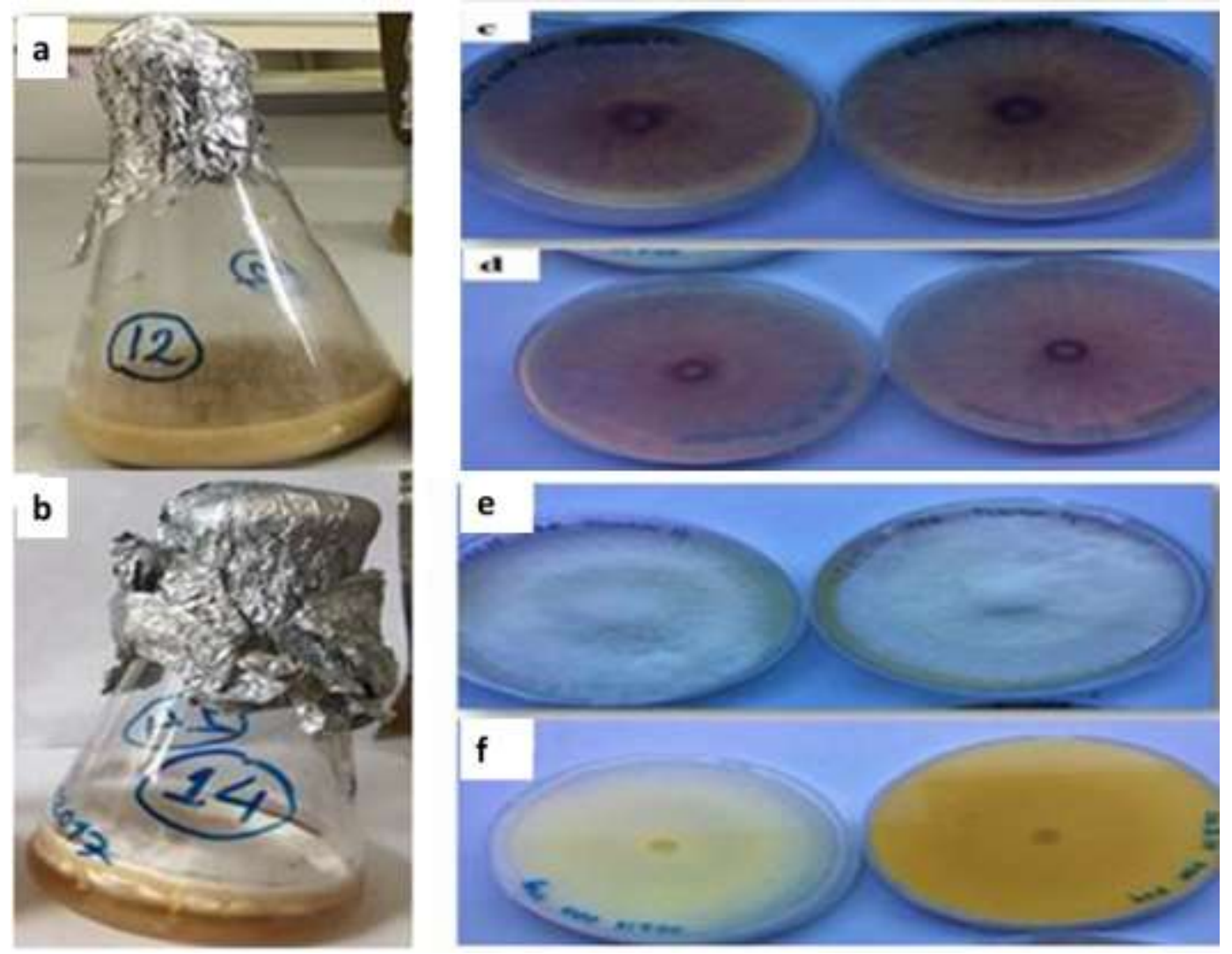

Şekil 2. Patates Dekstroz Broth ortamında a) FORL12 ve b) FOL14 race 2 izolatlarının gelişimi. Patates Dekstroz Agar (PDA) ortamında gelişen FORL12 izolatının üstten (c) ve alttan (d) görünümü ve FOL14 race 2 izolatının üstten (e) ve alttan (f) görünümleri.

Figure 2. The (a) FORL12 and (b) FOL14 race 2 isolates grown on Potato Dextrose Brother (PDB) and Potato Dextrose Agar (PDA) mediums. The grown FORL12 isolate adaxial (b) and abaxial (d), and FOL race 2 isolate adaxial (e) and abaxial (f) views.

\subsection{Bitkilerde hastalık gelişiminin değerlendirilmesi}

Patojenisite testlerinde TGRC den temin edilen 20 domates hatt1 FOL14 race 2 ve FORL12 izolatlarıla inokule edildikten sonra hastalık gelişimleri ilk hafta her gün, sonraki 14., 21. ve 28. günlerde değerlendirilmiştir. FOL14 race 2 ve FORL12 izotları ile inoküle edilen domates bitkilerindeki hastalık gelişmeleri aşağıdaki verilen 5 basamaklı $0-4$ skalası kullanılarak değerlendirilmiştir (Altınok ve Kamberoğlu 2005). Hastalık derecelendirmesinde kullanılan skala: 0: Gözle görülebilir hastalık simptomu yok, 1: Solgunluk başlangıcı, alt yapraklarda ince damarlarda renk açılması, 2: Bitkinin yarısında solgunluk, gelişme geriliği, klorosis ve nekrosis, 3: Genel solgunluk, yapraklarda kuruma, dökülme ve uçlardan geriye doğru ölüm, 4: Kuruma ve ölüm şeklindedir. (Chandler ve Santelman 1968; Altınok ve Kamberoğlu 2005). Çalışmalarda 
Hazera 5656 F1 bitkileri hassas negatif kontrol olarak kullanılmıştır.

\section{Bulgular}

Calıșmada FORL12 ve FOL14 race 2 izolatları ile testlenen 20 domates hattındaki hastalık gelişimleri 28 gün boyunca değerlendirilmiştir. Çalışmalarda LA3473 domates hattı hariç tüm domates hatları her iki patojene dayanıklı (hastalık skoru (HS: 0) bulunmuștur (Çizelge 1). FORL12 ile inokule edilen LA3473 domates bitkileri (HS: 4) kuruma ve ölüm belirtileri göstermiştir (Çizelge 1). Buna karş1lı LA3473 domates bitkileri FOL14 race 2 'ye karşı gözle görülebilir hastalık simptomu oluşturmayarak (HS: 0) dayanıklı fenotip göstermişlerdir (Çizelge 1). Hem FORL12 hem de FOL14 race 2 izolatlariyla inokule edilen Hazera 5656 F1 bitkilerinde tipik hastalık belirtileri (HS: 4) saptanmıştır. Gerek FORL12 gerekse FOL14 race 2 ile inokule edilen domates bitkilerinin köklerinden re-izolasyonlar yapılmış olup yalnızca LA3473, Hazera 5656 F1 domates bitkilerinin köklerinden Fusarium izolasyonları yapılabilmiştir. LA3473 ve Hazera 5656 F1 domates bitkilerinin köklerinden yeniden izole edilen fungus kolonileri mikroskobik ve morfolojik olarak değerlendirilmiş olup izole edilen fungusların LA3473 bitkisinde FORL12,
Hazera 5656 F1 bitkilerinde ise FORL12 ve FOL14 race 2 olduğu bulunmuştur (Şekil 3). Çalışmada diğer domates hatlarının köklerinden yapılan re-izolasyonlarda herhangi bir Fusarium etmeni gelişimi olmaz iken inokule edilen saksılardaki tüm torf-perlit karışımlarından yapılan reizolasyonlarda hem FORL12 hem de FOL14 race 2 etmenlerinin PDA besi ortamında çok geliştikleri bulunmuştur.

Patojenisite testlerinde kullanılan FORL12 ve FOL14 race 2 inokulasyonları sonucunda yalnızca LA3473 domates hattının FORL12 ile hastalanması (Şekil 3) nedeniyle çalışmada kullanılan 20 hat içerisinde en hassas hat olduğunu anlaşılmaktadır. Kullanılan iki Fusarium izolatı kendi arasında karşılaştırıldığında LA3473 domates hattında FORL12 izolatının tipik hastalık belirtisi göstermesi nedeniyle FOL14 race 2 izolatından daha virulent olduğu anlaşılmaktadır. Hassas Hazera 5656 F1 bitkileri her iki patojenle inokule edildikten kısa süre sonra yoğun Fusarium solgunluğu belirtileri gösterirken FOL14 race 2 ile inokule edilen bitkilerde inokulasyondan 14 gün sonra bitkilerde hastalı şiddetinde bir miktar azalma olurken FORL12 ile enfekteli Hazera 5656 F1 bitkilerin hastalı şiddetinde herhangi bir azalma belirlenmemiştir.

Çizelge 1. Fusarium oxysporum f.sp radicis-lycopersici12 ve Fusarium oxysporum f.sp lycopersici14 race 2 ile inokule edilen bitkilerdeki hastalık gelişimlerinin 0-4 skalasına göre değerlendirilmesi.

Table 1. Development of disease scores with Fusarium oxysporum f.sp radicis-lycopersici12 and Fusarium oxysporum f.sp lycopersici14 race 2 inoculated plants according 0-4 scale.

\begin{tabular}{lccccc}
\hline \multirow{2}{*}{ Domates Hattı ve Çeşit İsmi } & \multicolumn{2}{c}{ Hastalık Skoru } & \multirow{2}{*}{ Domates Hattı ve Çeşit İsmi } & \multicolumn{2}{c}{ Hastalık Skoru } \\
\cline { 2 - 4 } \cline { 5 - 6 } & FORL12 & FOL14 race 2 & & FORL12 & FOL14 race 2 \\
\hline LA0276 S. Lycopersicum & 0 & 0 & LA2818 S. lycopersicum & 0 & 0 \\
LA0490 S. Lycopersicum & 0 & 0 & LA2820 S. lycopersicum & 0 & 0 \\
LA0687 S. Lycopersicum & 0 & 0 & LA2830 S. lycopersicum & 0 & 0 \\
LA1312 S. Lycopersicum & 0 & 0 & LA2934 Solanum pimpinellifolium & 0 & 0 \\
LA1777 S. Habrochaites & 0 & 0 & LA3046 S. lycopersicum & 0 & 0 \\
LA1932 S. Chilense & 0 & 0 & LA3129 S. lycopersicum & 0 & 0 \\
LA1995 S. Lycopersicum & 0 & 0 & LA3473 S. lycopersicum & 4 & 0 \\
LA2444 S. Lycopersicum & 0 & 0 & LA4286 S. lycopersicum & 0 & 0 \\
LA2458 S. Lycopersicum & 0 & 0 & LA4440 S. lycopersicum & 0 & 0 \\
LA2779 S. Chilense & 0 & 0 & LA4442 S. lycopersicum & 0 & 0 \\
LA0276 S. Lycopersicum & 0 & 0 & LA2818 S. lycopersicum & 0 & 0 \\
\hline
\end{tabular}
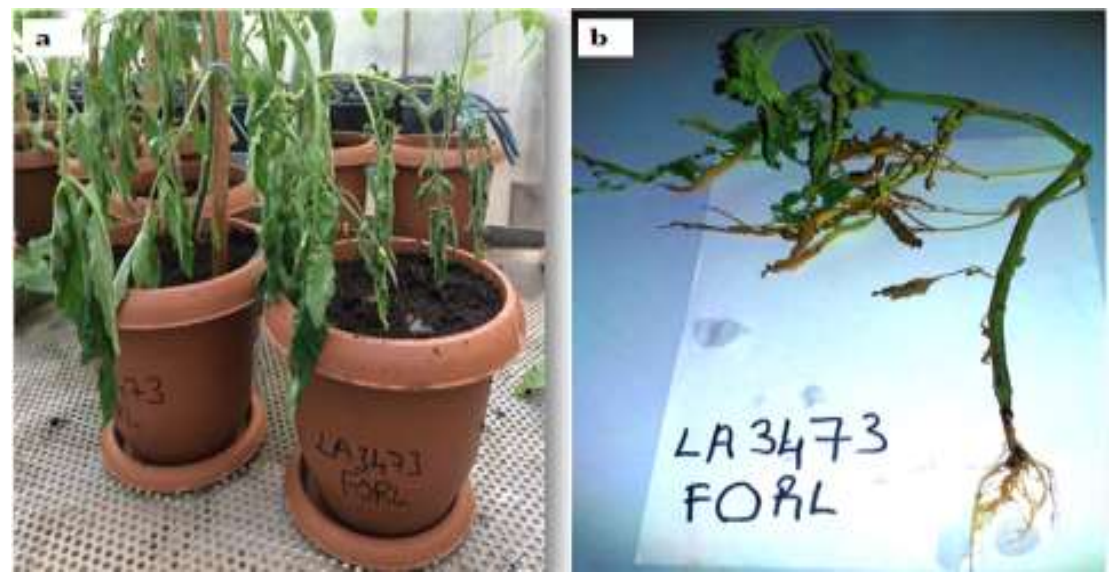

Şekil 3. FORL12 ile inokule edilen LA3473 domates hattının görünümü. a) Domates bitkilerinde genel solgunluk. b) LA3473 domates bitkisinde kök ve kök boğazında hastalık belirtisi.

Figure 3 Views of FORL12 with inoculated LA3473 tomato accession. a) Tomato plants have typical wilting appearance. b) LA3473 tomato accession has root and crown rot symptoms. 


\section{Tartışma}

Çalışmalarda kullanılan domates hatları içerisinde LA2830 (S. lycopersicum) FORL'ye karşı dayanıklılık sağlayan Frl geni içerirken LA0276 (S. lycopersicum), LA0490 (S. lycopersicum) ve LA4286 (S. lycopersicum) domates hatlarının FOL etmenine dayanıklılığı sağlayan $I$ geni içerdiği Domates Genetik Kaynaklar Merkezinde belirtilmektedir. Aynı Merkez LA4286 (S. lycopersicum) domates hattının FOL race 2'ye karş1 dayanıklılığı sağlayan I-2 geni içerdiğini belirtilmekte olup yapmış olduğumuz patojenisite testlerinde bu domates hatlarının FORL12 ve FOL14 race 2'ye dayanıklı bulunması nedeniyle bu hatlardaki dayanıklılık genlerinin testlenen Fusarium izolatlarına karşı hala dayanıklılığı sağladığı düşünülmektedir.

Fusarium türlerinin kontrolünde genetik olarak dayanıklılık genlerini içeren çeşitler geliştirmek için ıslah çalışmalarının en iyi yol olduğu belirlenmiştir (Morid ve ark. 2012). Benzer şekilde yaptığımız çalışmada kullanılan 20 TGRC domates hattından 19 tanesi FORL12 ye dayanıklı olduğu anlaşılmıştır. FORL12 ye hassas bulunan LA3473 domates hatt1 ayn1 zamanda FOL14 race 2'ye dayanıklı bulunmuştur. Gerek bu dayanıklı LA3473 gerekse diğer dayanıklı hatların Antalya domates üretim alanlarından izole edilen Fusarium etmenlerine dayanıklı bulunması gelecekte yapılacak 1slah çalışmaları için bir kaynak olarak kullanılabilme yolunu açmıştır. Yapılacak moleküler çalışmalar ile bu dayanıklı çeşitlerdeki genlerin bilinen genlerle aynı ya da farklı allel genlerden kaynaklandığı yada Fusarium izolatlarındaki patojenisiteye etki eden avirulenslik genlerinin ortaya konabilmesi için önemlidir.

Yapılan çalışmalarda FORL ile ilgili genetik dayanıklılığın tek bir baskın $F r l$ geni tarafindan sağlandığı Roberts ve ark. (2001) tarafından bildirilmiştir. Bu Frl genin domatesin 9. kromozomunda yer aldığ 1 aynı zamanda domateste Tobacco Mosaic Virus'e dayanıklılığı sağlayan resesif $T m$-2 genine yakın yerde (> $5 \mathrm{cM}$ ) bulunduğu belirlenmiştir (Fazio ve ark. 1999; Vakalounakis ve ark. 1997). Benzer bir şekilde çalışmamızda FORL12 izolatına dayanıklılık sağlayan domates hatlarının TMV hastalık etmeni ya da onun günümüzde problem olan Tomato brown rugose fruit virus (ToBRFV) ile testlenmesiyle bu önemli virüs hastalığı genetik olarak kontrol altına alınabilecektir.

Yaptığımız ön çalışmalar, izole edilen 18 Fusarium izolatı içinde FOL14 race 2 ve FORL12 izolatlarının en virulent izolatlar olduğunu ortaya koymuştur. Nitekim burada kullanılan FORL12 ve FOL14 race 2 izolatlarının testlenn 20 bitki hatt1 üzerinde FORL12 izolatının daha virulent olduğunu göstermektedir. Bu sonuçlar Fusarium izolatlarının konukçu bitkiyi enfekte edebilmek için farklı avirulent genlerini kullandığını ve konukçu bitkide ortak yada farklı dayanıklılık gen(ler)i hedef aldığını göstermektedir. Nitekim gelecekte kalıcı genetik bir dayanıklılık için moleküler olarak FOL ve FORL etmenlerinin sahip olduğu avirulent genlerinin bitki dayanıklılık genleriyle olan etkileşimlerini (Garcia ve ark. 2018) ortaya koyabilmek için Fusarium effektör genleri ve konukçu domates bitkisi ilişkileri laboratuvarımızda araştırılmaktadır.

Hastalıkların kontrolünde kimyasal ilaçların kullanımı en kolay ve en etkili yol gibi görünmekle birlikte, kimyasalların kalıcı etkilerinin insan ve çevre sağlığ 1 yönünden doğurduğu tehlike göz önünde tutulursa hastalıklara karşı dayanıklı çeşit kullanımının önemi kendiliğinden ortaya çıkmaktadır. FOL ve FORL hastalık etmenlerine karşı dayanıklı hatların belirlenmesi, bunlardaki farklı dayanıklılık mekanizmalarının karakterize edilmesi ve gelecekte dayanıklı bitkilerin kullanılması bugünden yarın için yapılması gereken bir yatırım olarak değerlendirilmelidir.

Akdeniz Bölgesi'nde örtü altı domates yetiştiriciliğinde FOL ve FORL hastalık etmenleri neden olduğu solgunluk hastalığı her yıl ciddi sorunlar oluşturmaktadır (Yücel ve Çınar, 1989). Fusarium solgunlukları olarak bilinen bu hastalıklara karşı dayanıklı çeşitler kullanılmaktadır (Can ve ark. 2004; Çolak ve Biçici 2011; 2012). Ancak yurtdışından dayanıklı olarak getirilen domates çeşitleri Türkiye'deki Fusarium izolatlarıyla test edilmediği için bu dayanıklı olarak bilinen çeşitler FOL ve FORL karşı hassaslık göstermektedirler (Hajlaoui ve ark. 2001; Hibar 2007). Bu çalışmayla ilk defa Antalya domates üretim alanlarından izole edilen Fusarium solgunluk etmenleri; FORL12 ve FOL14 race 2 dünyaca bilinen TGRC domates hatları ile testlenerek fenotipik ve genotipik özellikleri belirlenmiştir.

\section{Sonuç}

Patojenisite testlerinde dayanıklı olduğu bulunan LA0276, LA0490, LA0687, LA1312-3, LA1777, LA1932, LA1995, LA2444, LA2458, LA2779, LA2818, LA2820, LA2830, LA2934, LA3046, LA3129, LA4286, LA4440, LA4442 domates hatlarının ilk etapta anaç olarak kullanımı, sonrasında yapılacak moleküler çalışmalar ile dayanıklı bitkilerin üretimine olanak sağlanacaktır. Mevcut dayanıklılık kaynakları olarak kullanılan domates bitkilerine karşı alternatif bir dayanıklılık kaynağ olarak dayanıklı bitkilerin bulunmasıyla bu hastalık etmenlerine dayanıklı olarak bulunan domatesler üzerine aşı yapılacak elit domatesler ile fungal etmenden etkilenmeden üretim yapılması k1sa vadede sağlanabilecektir. Dayanıklılıkla birlikte uygulanacak ıslah yöntemleri, biyoteknolojik uygulamalar ile Fusarium hastalıkları tamamen kontrol edilebilecektir $\mathrm{Bu}$ çalışma toprak kökenli hastalık etmeni Fusarium'a karşı dayanıklılık kaynaklarını açıkça ortaya koymaktadır.

\section{Kaynaklar}

Agrios GN (2005) Plant pathology. Fifth edition, Elsevier Press, Amsterdam.

Aktaş S (2015) Domates öz nekrozuna neden olan etmenlere karşı pgpr ve biyoajan bakterileri kullanılarak kontrollü koşullarda biyolojik mücadele imkânlarının araştırılması. Yüksek Lisans Tezi, Atatürk Üniversitesi Fen Bilimleri Enstitüsü, Erzurum.

Altınok HH, Kamberoğlu MA (2005) Adana ve Mersin illerinde patlıcan üretim alanlarında Fusarium ve Verticillium solgunluk hastalıklarının yaygınlığı ve şiddeti. Çukurova Üniversitesi Ziraat Fakültesi Dergisi 20: 1-8.

Aşkın A, Katırcıoğlu Z (2008) Ankara ili ayaş, beypazarı ve nallıhan ilçelerindeki domates fideliklerinde çökerten hastalığına neden olan bazı fungal patojenlere karşı patojen olmayan pseudomonas'ların etkisinin belirlenmesi. Ankara Üniversitesi Fen Bilimleri Enstitüsü Doktora Tezi, Ankara.

Blancard D (1994) A colour atlas of tomato diseases observation, identification and control. INRA Vegetable Pathology Unit France.

Can C, Yucel S, Korolev N, Katan T (2004) First report of fusarium crown and root rot of tomato caused by Fusarium oxysporum f.sp. radicis-lycopersici in Turkey. Plant Pathology 53: 814-814.

Catanzariti AM, Lim GTT, Jones DA (2014) The tomato I-3 gene: a novel gene for resistance to Fusarium wilt disease. New Phytogist 207: 106-118.

Chandler JM, Santelman PW (1968) Interaction of four herbicides with Rhizoctonia solani on seedling cotton. Weed Science 16: 453-454. 
Çolak A, Biçici M (2011) Doğu Akdeniz bölgesi örtü altı domates yetiştiriciliğinde Fusarium oxysporum special formlarınının simptomatolojik ayrımı ile solgunluk ve kök- kök boğazı çürüklüğü hastalıklarının çıkış, şiddet ve yaygınlıklarının belirlenmesi. Bitki Koruma Bülteni 51: 331-345.

Çolak A, Biçici M (2012) PCR detection of Fusarium oxysporum f.sp. radicislycopersici and races of $F$. oxysporum f.sp. lycopersici of tomato in protected tomato growing areas of Eastern Mediterranean Region of Turkey. Turkish Journal of Agriculture and Forestry 37: 457-467.

Devran Z, Kahveci E, Hong Y, Studholme D, Tör M (2018) Identifying molecular markers suitable for Frl selection in tomato breeding. Theoretical and Applied Genetics 131: 1-7.

FAO (2020) Food and Agriculture Organization of the United Nations. At http://www.fao.org/statistics/en/ Erişim 17 Nisan 2020.

Fazio G, Stevens M, Scott JW (1999) Identification of RAPD markers linked to Fusarium crown and root rot resistance (Frl) in tomato. Euphytica 105: 205-210.

Garcia E, Benavides A, Flores M, Robledo A, Juarez A, Gonzalez S (2018) A moleculer vision of the interaction of tomato plants and Fusarium oxysporum f. sp. lycopersici. Plant Diseases. Intechopen.722127.

Gordon TR, Martyn RD (1997) The evolutionary biology Fusarium oxysporum. Annual Review of Phytopathology 35: 111-128.

Hajlaoui MR, Hamza N, Gargouri S, Guermech A (2001) Apparition en Tunisie de Fusarium oxysporum f.sp. radicis- lycopersici, agent de la pourriture des racines et du collet de la tomate. OEPP/EPPO Bulletin 31: 505-507.

Hibar K, Edel-Herman V, Steinberg C, Gautheron N, Daami-Remadi M, Alabouvette C, El Mahjoub M (2007) Genetic diversity of Fusarium oxysporum populations isolated from tomato plants in Tunusia. Journal of Phytopathology 155: 136-142.

Jarvis WR, Shoemaker RA (1978) Taxonomic status of Fusarium oxysporum causing foot and root rot of tomato. Phytopathology 68 : $1679-1680$.
Jones JB, Jones JP, Stall RE, Zitter TA (1991) Compendium of Tomato Diseases. American Phytopathological Society, St. Paul, USA.73.

Morid B, Hajmansoor S, Kakvan N (2012) Screening of resistance genes to fusarium root rot and fusarium wilt diseases in tomato (Lycopersicon esculentum) cultivars using RAPD and CAPs markers. Pelegia Research Library 2: 931-939.

Paksoy M (2003) Konya ekolojisinde değișik ekim-dikim zamanlarında yetiştirilen bazı sanayilik domates çeşitlerinde verim ve kalite özelliklerinin incelenmesi, Selçuk Üniversitesi Ziraat Fakültesi Dergisi 17: 6-9.

Roberts PD, Mcgovern RJ, Datnoff LE (2001) Fusarium crown and root rot of tomato in Florida. University of Florida, IFAS Extension.

Snyder WC; Hansen HN (1940) The species concept in Fusarium. American Journal of Botany 27: 64-67.

TÜIKK (2019) Türkiye İstatistik Kurumu. https://biruni.tuik.gov.tr/bolgeselistatistik Erişim 07 Mayıs 2020.

Türkomp (2016) Ulusal Gida Kompozisyon veri tabanı athttp:/turkomp.gov.tr/main. Erişim 11 Nisan 2020.

Vakalounakis DJ, Laterrot H, Moretti A, Ligoxigakis EK, Smardas K (1997) Linkage between Frl (Fusarium oxysporium f.sp. radicislycopersici resistance) and Tm-2 (Tobacco mosaic virus resistance2) loci in tomato (Lycopersicon esculentum). Annual Applied Biology 130: 319-323.

Vellaisamy R, Thiruvengadam R, Ramasamy S (2002) Induction of defense-related protein in tomato roots treated wth Pseudomonas fluorescens Pf1 and Fusarium oxysporum f. sp. lycopersici. Plant and Soil 239: 55-68.

Yücel S, Çınar A (1989) Domates Fusarium solgunluğuna (fusarium oxysporum schlecht, f.sp. lycopersici (sacc.) snyd. and hans) karǵ1 biyolojik kontrolde antagonistlerin ve toprak solarizasyon uygulamasının etkileri. Türk Tarım ve Ormancılık Dergisi 13: $1372-1393$. 